Article

\title{
Peptide/Peptoid Hybrid Oligomers: The Influence of Hydrophobicity and Relative Side-Chain Length on Antibacterial Activity and Cell Selectivity
}

\author{
Nicki Frederiksen ${ }^{(D)}$, Paul R. Hansen $(D$, Fredrik Björkling and Henrik Franzyk * (D) \\ Department of Drug Design and Pharmacology, Faculty of Health and Medical Sciences, University of \\ Copenhagen, Jagtvej 162, DK-2100 Copenhagen, Denmark; nicki.frederiksen@sund.ku.dk (N.F.); \\ prh@sund.ku.dk (P.R.H.); fb@sund.ku.dk (F.B.) \\ * Correspondence: henrik.franzyk@sund.ku.dk; Tel.: +45-3533-6255
}

Received: 29 October 2019; Accepted: 26 November 2019; Published: 4 December 2019

\begin{abstract}
Previous optimisation studies of peptide/peptoid hybrids typically comprise comparison of structurally related analogues displaying different oligomer length and diverse side chains. The present work concerns a systematically constructed series of 16 closely related 12-mer oligomers with an alternating cationic/hydrophobic design, representing a wide range of hydrophobicity and differences in relative side-chain lengths. The aim was to explore and rationalise the structure-activity relationships within a subclass of oligomers displaying variation of three structural features: (i) cationic side-chain length, (ii) hydrophobic side-chain length, and (iii) type of residue that is of a flexible peptoid nature. Increased side-chain length of cationic residues led to reduced hydrophobicity till the side chains became more extended than the aromatic/hydrophobic side chains, at which point hydrophobicity increased slightly. Evaluation of antibacterial activity revealed that analogues with lowest hydrophobicity exhibited reduced activity against $E$. coli, while oligomers with the shortest cationic side chains were most potent against $P$. aeruginosa. Thus, membrane-disruptive interaction with $P$. aeruginosa appears to be promoted by a hydrophobic surface of the oligomers (comprised of the aromatic groups shielding the cationic side chains). Peptidomimetics with short cationic side chains exhibit increased hemolytic properties as well as give rise to decreased HepG2 (hepatoblastoma G2 cell line) cell viability. An optimal hydrophobicity window could be defined by a threshold of minimal hydrophobicity conferring activity toward E. coli and a threshold for maximal hydrophobicity, beyond which cell selectivity was lost.
\end{abstract}

Keywords: antimicrobial peptides; peptoids; peptidomimetics; solid-phase synthesis; antibacterial activity; structure-activity study; hemolysis; cell viability; cell selectivity; hydrophobicity

\section{Introduction}

Increased emergence of bacterial strains resistant to antibiotics is a serious worldwide concern for human health. Major factors contributing to the selection for multidrug-resistant (MDR) strains comprise the widespread non-prescription sales of antibiotics in some countries [1] and lack of rapid methods for identification of the specific bacteria causing an infection-with the ensuing prescription of inefficacious antibiotics [2]. Together, these issues promote development of resistance, which ultimately may give rise to pan-resistant strains due to inappropriate use of "last-resort" antibiotics [3,4], and consequently, there is an urgent need for the continuous discovery of new antibiotics. Mechanisms of antimicrobial resistance (AMR) typically confer resistance toward a group of related drugs belonging to the same class of antibiotics. Hence, it is not a viable long-term approach merely to develop analogues of existing drugs, since only entirely new classes of antibiotics may retain a prolonged usage time without the development of severe resistance problems. 
Antimicrobial peptides (AMPs) constitute a class of potential antibiotics with an alternative mode of action, and they have evolved to play important roles in the innate immune systems of nearly all living organisms [5], often exhibiting broad-spectrum antibacterial activity [6]. Structurally, AMPs are very diverse, but the majority of known AMPs adopt amphipathic structures and possess a characteristic high overall positive charge, which confers selectivity for bacterial cells over mammalian cells $[7,8]$. A major challenge in the development of drugs from AMP-based leads is their low proteolytic stability. Approaches that confer increased stability comprise incorporation of D-amino acids [9,10] or design of unnatural mimetics, e.g., $\alpha$-peptoids (N-alkylated glycine oligomers) [11,12], $\beta$-peptoids (N-alkylated $\beta$-alanine oligomers) [13], $\beta$-peptides [14], $\alpha / \beta^{3}$-peptides [15], $\alpha$-peptide $/ \beta$-peptoid hybrids [16], $\alpha / \gamma$ $\mathrm{N}$-acylated N-aminoethylpeptides (AApeptides) [17,18], and oligo-acyl-lysyls (OAKs) [19].

Many AMPs fold into $\alpha$-helices or adopt secondary structures that are amphipathic and considered essential for high antibacterial activity $[8,20]$. In several studies a correlation between degree of helicity and undesired toxicity of AMPs toward mammalian cells was found [20-29]. Furthermore, $\alpha / \beta^{3}$-peptides and peptide/peptoid hybrids with a low degree of amphipathicity and/or secondary structure were shown to possess advantageous activity profiles [15,30]. Interestingly, CD (circular dichroism) spectroscopy proved to be of little value in the characterization of peptide/peptoid hybrid oligomers with an alternating cationic/hydrophobic design, since it was not feasible to assign a secondary structure (e.g., $\alpha$-helical, $\beta$-sheet or random coil) based on their CD spectra, which did not correspond to any known type of folding [30,31]. In addition, crystallisation attempts for such hybrid oligomers have failed so far. Analogues displaying $\alpha$-chiral side chains in the peptoid residues gave rise to the most distinct $C D$ spectra inferring some degree of secondary structure in the presence of liposomes mimicking bacterial or mammalian membranes [30,31]. This in combination with the finding that oligomers devoid of $\alpha$-chiral peptoid residues possess the most favourable activity profiles indicate that for these oligomers secondary structure is not a prerequisite for antibacterial activity-in fact it appears only to confer undesirable side effects in the presence of mammalian cells. Moreover, these hybrid oligomers did not exhibit a similar characteristic CD behaviour as reported for peptoid oligomers displaying $\alpha$-chiral side chains [32].

Both for AMPs and helix-forming $\alpha / \beta^{3}$-peptide hybrids, increased hydrophobicity has been correlated with higher antibacterial potency and hemolytic properties [15,33-37]. For lysine-based peptide/ $\beta$-peptoid hybrids and peptoid oligomers, it was found that, above a certain threshold for hydrophobicity, the compounds lost selectivity for bacteria over mammalian erythrocytes $[32,38,39]$. Various structural modifications that change the overall hydrophobicity of AMPs and peptidomimetics as well as their effects on the biological activity profiles of the resulting analogues have been reported in several studies. These modifications include single amino acid substitutions [40], multiple amino acid substitutions [41], alteration of net charge [34], incorporation of fluorinated residues [42], and appending end groups influencing polarity (i.e., end-tagging with oligopeptides, hydrophobic, polar, or cationic moieties) [43-52].

Inspired by the above-mentioned observations regarding the putative interplay between activity and hydrophobicity, we decided to perform a more comprehensive study also including the so far poorly explored influence of relative side-chain length as a potential determining factor for antibacterial activity, hemolysis, and effect on cell viability. Previous structure-activity studies of peptide/peptoid hybrids with an alternating cationic/hydrophobic design [53] have shown that such oligomers exert promising antibacterial activity while exhibiting weak hemolytic activity and low effect on mammalian cell viability as compared to the corresponding peptides [31], and that 12-mer oligomers display the optimal cell selectivity [30]. Thus, a series of related 12-mer peptide/peptoid hybrids, displaying elongated/truncated side chains via the incorporation of homologues of lysine/phenylalanine and the corresponding peptoid residues, was investigated in order to identify trends for how structural features influence their activity profile. These peptidomimetics were tested against a panel of seven bacterial strains comprising representatives of the ESKAPE bacteria (E. faecalis, S. aureus, K. pneumoniae, A. baumannii, P. aeruginosa, and E. coli) [54]. 


\section{Results and Discussion}

\subsection{Selection and Synthesis of Peptidomimetics}

Recently, we reported that a peptide/ $\beta$-peptoid hybrid oligomer with elongated side chains display equal or slightly higher antibacterial activity against $S$. pseudintermedius and P. aeruginosa as compared to the Lys/ $\beta$ NPhe template with identical oligomer length $[42,55]$. Intrigued by these findings we designed 16 similarly related peptide/ $\alpha$-peptoid oligomers $\mathbf{1 - 1 6}$, see Figure 1 , in order to determine whether hydrophobicity and/or relative side-chain length may be clearly correlated to antibacterial potency and/or effect on mammalian cell viability. Comparison with the corresponding peptide was omitted since, for a very closely related 16-mer, both the all-D- and all-L-peptide exhibited exceedingly high toxicity toward mammalian cell lines (i.e., $\mathrm{IC}_{50}$ values of $\sim 20 \mu \mathrm{M}$ ) while exhibiting poor antibacterial activity (i.e., MICs of $128 \mu \mathrm{M}$ or above) [31].

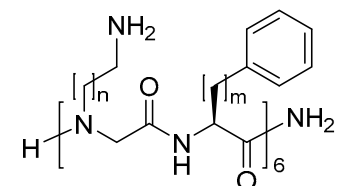

$$
\begin{aligned}
& 1 \mathrm{n}=1, \mathrm{~m}=1 \\
& 2 \mathrm{n}=2, \mathrm{~m}=1 \\
& 3 \mathrm{n}=3, \mathrm{~m}=1 \\
& 4 \mathrm{n}=4, \mathrm{~m}=1 \\
& 5 \mathrm{n}=1, \mathrm{~m}=2 \\
& 6 \mathrm{n}=2, \mathrm{~m}=2 \\
& 7 \mathrm{n}=3, \mathrm{~m}=2 \\
& \mathbf{8} \mathrm{n}=4, \mathrm{~m}=2
\end{aligned}
$$

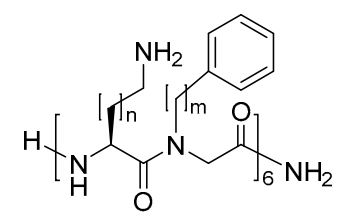

$$
\begin{aligned}
& 9 \mathrm{n}=1, \mathrm{~m}=1 \\
& 10 \mathrm{n}=2, \mathrm{~m}=1 \\
& 11 \mathrm{n}=3, \mathrm{~m}=1 \\
& 12 \mathrm{n}=4, \mathrm{~m}=1 \\
& 13 \mathrm{n}=1, \mathrm{~m}=2 \\
& 14 \mathrm{n}=2, \mathrm{~m}=2 \\
& 15 \mathrm{n}=3, \mathrm{~m}=2 \\
& 16 \mathrm{n}=4, \mathrm{~m}=2
\end{aligned}
$$

Figure 1. Structures of $\alpha$-peptide/ $\alpha$-peptoid hybrid peptidomimetics.

The peptidomimetics were synthesised by using Fmoc-based solid-phase peptide synthesis (SPPS) methodology for assembly of commercial amino acid and preformed peptoid building blocks (i.e., 17-22). The Fmoc-protected peptoid building blocks were prepared essentially as previously described [30,56]: The primary amine corresponding to the desired side chain was alkylated with ethyl 2-bromoacetate or tert-butyl 2-bromoacetate to provide an intermediate that subsequently was hydrolysed and Fmoc-protected to yield the desired peptoid building block (see Figure 2). Importantly, the cationic peptoid building blocks 17-20 could all be obtained in pure state on a multigram scale via an extraction work-up process followed by crystallisation.

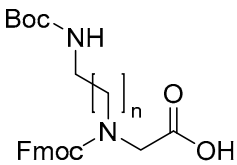

$$
\begin{aligned}
& 17 n=1 \\
& 18 n=2 \\
& 19 n=3
\end{aligned}
$$$$
20 \mathrm{n}=4
$$

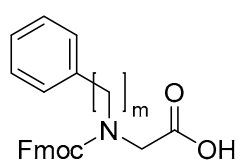

$21 \mathrm{~m}=1$

$22 \mathrm{~m}=2$

Figure 2. Structures of peptoid building blocks.

\subsection{Effects of Relative Side-Chain Length and Flexibility on Hydrophobicity}

The investigated peptidomimetics (see Figure 1) may be considered to comprise two main groups, consisting either of alternating cationic peptoid residues and hydrophobic amino acid residues (i.e., 1-8) or of alternating cationic amino acid residues and hydrophobic peptoid residues (i.e., 9-16). Four different lengths of the cationic side chains and two different lengths of the hydrophobic side chains were selected in order to obtain analogues within a sufficiently wide range of hydrophobicity so 
that the entire series was expected to comprise compounds with a substantial variation in antibacterial and/or hemolytic properties. Analogues displaying further extended hydrophobic side chains were not included since analogous peptide/ $\beta$-peptoid hybrids were found to be poorly soluble in the test media and were found to be devoid of cell selectivity [55].

Thus, the peptidomimetics included in the present study represent variation of three structural features: (i) Cationic side-chain length (2-5 carbon atoms), (ii) hydrophobic side-chain length (benzyl or phenylethyl), and (iii) the type of residue that is of a flexible peptoid nature (i.e., cationic versus hydrophobic). Accordingly, the peptidomimetics can be further subdivided into four subgroups (I-IV), each having similar type of hydrophobic residues and nature of peptoid residues but with varying cationic side-chain length. Thus, subgroups I-IV comprise peptidomimetics 1-4, 5-8, 9-12, and 13-16, respectively.

The relative hydrophobicity of each peptidomimetic was measured by reverse-phase high-performance liquid chromatography (RP-HPLC). Typically, the RP-HPLC retention time (or percentage acetonitrile at peak elution) constitutes the preferred measure that allows for comparison of relative hydrophobicity, while $\log \mathrm{P}$ values of polycationic peptides or peptidomimetics normally are considered unsuitable due to the extreme hydrophilic nature of such compounds [11,45,57-60]. Comparison of the hydrophobicity of the members of all four subgroups (see Table 1) indicates that subgroup I (with cationic peptoid residues and Phe, i.e., 1-4) and subgroup II with cationic peptoid residues and homophenylalanine (hPhe) (i.e., 5-8) display the largest differences in hydrophobicity between the least and most hydrophobic representative within each subgroup. For both subgroups III (with cationic amino acid residues and the peptoid analogue of Phe, NPhe, i.e., 9-12) and IV (with cationic amino acid residues and the peptoid analogue of hPhe, NhPhe, i.e., 13-16) only minor differences in hydrophobicity were seen. These observations infer that, when the cationic residues are of a peptoid nature, the side-chain length of these has a strong influence on the hydrophobicity. Expectedly, subgroups I and III, containing either Phe or NPhe, had a relatively low hydrophobicity ( peak elution within the ranges 35.6-37.5\% and 36.9-38.0\% MeCN, respectively), while subgroups II and IV, containing hPhe and NhPhe, both displayed a comparably higher hydrophobicity (eluting within the ranges $40.6-43.5 \%$ and $40.5-41.4 \% \mathrm{MeCN}$, respectively). Thus, introduction of additional six methylene groups results, as expected, in increased hydrophobicity.

Within each subgroup, a somewhat surprising trend is seen — increased cationic side-chain length leads to reduced hydrophobicity. This may be explained by the cationic amino groups becoming gradually more accessible to the surroundings (due to lower shielding by the aromatic groups of the hydrophobic residues) when extending the corresponding side-chain length. In particular, for the peptidomimetics containing 2,4-diaminobutyric acid (Dab) or its peptoid analogue (i.e., NDab) this effect was pronounced, and these analogues was the most hydrophobic ones within each subgroup. When comparing these analogues with those containing ornithine (Orn) or its peptoid analogue (i.e., NOrn), the incorporation of additional methylene groups, expected to confer an increase in hydrophobicity, was clearly counteracted by a larger decrease in hydrophobicity induced by a reduced shielding of the amino functionalities by the aromatic groups, resulting in an overall decrease in hydrophobicity. A similar trend was seen for the hydrophobicity when comparing the peptidomimetics containing Orn or NOrn with the corresponding analogues displaying Lys or the peptoid analogue of Lys (i.e., NLys). By contrast, the peptidomimetic in each group that contained homolysine (hLys) or its peptoid analogue (i.e., NhLys) did not follow this trend, as they consistently possessed a higher hydrophobicity than the corresponding Lys/NLys analogues. For these peptidomimetics, the shielding of the cationic amino groups by the aromatic side chains appears to be surpassed already, and hence the opposite hydrophobicity enhancement conferred by the incorporation of additional methylene groups in the cationic side chains dominates. 
Table 1. Minimal inhibitory concentrations (MICs) for peptidomimetics 1-16.

\begin{tabular}{|c|c|c|c|c|c|c|c|c|c|}
\hline \multirow{3}{*}{ Subgroup } & \multirow{3}{*}{ Cmpd } & \multirow{3}{*}{$\begin{array}{c}\text { Hydrophobicity } \\
\text { (\% MeCN at } \\
\left.\text { elution }^{\mathrm{a}}\right)\end{array}$} & \multicolumn{7}{|c|}{ MIC $(\mu \mathrm{g} / \mathrm{mL})$} \\
\hline & & & \multicolumn{5}{|c|}{ Gram-Negative } & \multicolumn{2}{|c|}{ Gram-Positive } \\
\hline & & & $\begin{array}{c}\text { E. coli ATCC } \\
25922\end{array}$ & $\begin{array}{l}\text { K. pneumoniae } \\
\text { ATCC } 13883\end{array}$ & $\begin{array}{c}\text { P. aeruginosa } \\
\text { ATCC } 27853\end{array}$ & $\begin{array}{l}\text { P. aeruginosa } \\
\text { PAO1 }\end{array}$ & $\begin{array}{l}\text { A. baumannii } \\
\text { ATCC } 19606\end{array}$ & $\begin{array}{c}\text { S. aureus } \\
\text { ATCC } 29213\end{array}$ & $\begin{array}{c}\text { E. faecalis } \\
\text { ATCC } 29212\end{array}$ \\
\hline $\mathbf{I}$ & 1 & $37.5 \%$ & $4-8$ & 64 & 64 & $>64$ & $>64$ & $>64$ & $>64$ \\
\hline $\mathbf{I}$ & 2 & $35.7 \%$ & $8-16$ & 64 & $>64$ & $>64$ & $>64$ & $>64$ & $>64$ \\
\hline $\mathbf{I}$ & 3 & $35.6 \%$ & $8-16$ & 32 & $>64$ & $>64$ & $>64$ & $>64$ & $>64$ \\
\hline $\mathbf{I}$ & 4 & $36.6 \%$ & $4-8$ & 64 & $>64$ & $>64$ & 64 & $>64$ & $>64$ \\
\hline II & 5 & $43.5 \%$ & 4 & 64 & 4 & 16 & $>64$ & 8 & 32 \\
\hline II & 6 & $41.2 \%$ & 4 & $>64$ & 8 & $16-32$ & $>64$ & 16 & $>64$ \\
\hline II & 7 & $40.6 \%$ & $2-4$ & $>64$ & 32 & $32-64$ & $>64$ & $>64$ & $>64$ \\
\hline II & 8 & $40.9 \%$ & 2 & 64 & 64 & 64 & 4 & $>64$ & $>64$ \\
\hline III & 9 & $38.0 \%$ & $2-4$ & $32-64$ & 1 & 2 & $16-32$ & $>64$ & $>64$ \\
\hline III & 10 & $37.2 \%$ & $4-8$ & $>64$ & $2-4$ & $4-8$ & $64->64$ & $>64$ & $>64$ \\
\hline III & 11 & $36.9 \%$ & $4-8$ & 64 & 4 & $8-16$ & $>64$ & $>64$ & $>64$ \\
\hline III & 12 & $38.0 \%$ & 2 & $>64$ & 64 & 64 & 16 & $>64$ & $>64$ \\
\hline IV & 13 & $41.4 \%$ & 4 & 32 & 2 & $2-4$ & $>64$ & $>64$ & $>64$ \\
\hline IV & 14 & $40.5 \%$ & $4-8$ & 32 & 8 & $8-16$ & $>64$ & $>64$ & $>64$ \\
\hline IV & 15 & $40.5 \%$ & 4 & $>64$ & 16 & $8-16$ & 64 & $>64$ & $>64$ \\
\hline \multirow[t]{2}{*}{ IV } & 16 & $41.1 \%$ & 4 & $>64$ & 16 & 32 & 8 & $>64$ & $>64$ \\
\hline & Colistin & & $0.125-0.25$ & 0.25 & $0.125-0.25$ & 0.5 & 0.5 & $>64$ & $>64$ \\
\hline
\end{tabular}

${ }^{a}$ RP-HPLC gradient: $0 \rightarrow 60 \%$ B (during $10 \mathrm{~min}$ ). MeCN: acetonitrile. 
Analysis of similar hydrophobicity data were reported in a previous study concerning 14-mer AMPs containing hydrophobic, branched amino acids and cationic amino acids [57]. Here the relative hydrophobicity of $\mathrm{H}$-Gly-(Ile-Ile-Lys-Lys) ${ }_{3}-\mathrm{Ile}-\mathrm{NH}_{2}$ and $\mathrm{H}$-Gly-(Ile-Ile-Orn-Orn) ${ }_{3}-\mathrm{Ile}-\mathrm{NH}_{2}$ was compared, and the Lys-containing AMP (displaying an additional six methylene groups) was as expected more hydrophobic than the corresponding Orn analogue. However, when comparing the Orn analogue with the Dab analogue, and likewise the Dab analogue with the 2,3-diaminopropionic acid (Dap) analogue, the peptides with the shorter cationic side chains were more hydrophobic, most likely due to the cationic charges being partially shielded by the Ile residues. Interestingly, in the present study, the least hydrophobic compounds within each subgroup were the Lys/NLys analogues $(\mathbf{3}, 7, \mathbf{1 1}$, and 15), while in the above case of Ile-containing peptides, it was the Orn analogue, which may be ascribed to the fact that Phe/NPhe and hPhe/NhPhe all are larger in size than Ile.

\subsection{Effects of Relative Side-Chain Length and Flexibility on Antibacterial Activity}

The antibacterial activity (see Table 1) of the peptidomimetics was tested against a panel of four Gram-negative bacteria (E. coli, K. pneumoniae, P. aeruginosa, and A. baumannii) and two Gram-positive bacteria (E. faecalis and $S$. aureus). None of the peptidomimetics displayed noteworthy activity against K. pneumoniae (MIC values $\geq 32 \mu \mathrm{g} / \mathrm{mL}$ ), which corroborates previous findings that Lys-based peptide/peptoid and peptide/ $\beta$-peptoid hybrids as well as other related peptidomimetics generally lack potency against $K$. pneumoniae $[31,58-61]$. Only four peptidomimetics $(\mathbf{8}, \mathbf{9}, \mathbf{1 2}$, and $\mathbf{1 6})$ had MIC values below $32 \mu \mathrm{g} / \mathrm{mL}$ against $A$. baumannii, and three of these compounds contained hLys or NhLys, while the most potent oligomers (i.e., 8 and 16 having MIC values of 4 and $8 \mu \mathrm{g} / \mathrm{mL}$, respectively) contained hPhe or NhPhe, which implies that extended side chains of both cationic and hydrophobic residues appear to confer activity toward $A$. baumannii.

All 16 peptidomimetics were active against $E$. coli, and most of these had a MIC in the range 4-8 $\mu \mathrm{g} / \mathrm{mL}$. Two exceptions were peptidomimetics 2 and 3 with slightly lower potency (i.e., MICs of $8-16 \mu \mathrm{g} / \mathrm{mL}$ ) than the other compounds in subgroup I (i.e., 1 and 4 with a MIC of $4-8 \mu \mathrm{g} / \mathrm{mL}$ ). Comparison of compounds $\mathbf{2}$ and $\mathbf{3}$ with peptidomimetics with the same cationic residues in subgroup II (i.e., 6 and 7 with MIC of $2-4 \mu \mathrm{g} / \mathrm{mL}$ ) as well as with the analogues having a reversed amino acid/peptoid design in subgroup III (i.e., 10 and $\mathbf{1 1}$ with MICs of $4-8 \mu \mathrm{g} / \mathrm{mL}$ ) showed that compounds 2 and 3 exhibited slightly lower antibacterial activity. Slightly higher MIC values against $E$. coli were observed for peptidomimetics in subgroup I as compared to those in subgroup II, possibly due to the additional methylene groups in the side chains of hPhe (as compared to Phe). By contrast all members of subgroups III and IV that displayed cationic amino acid residues were almost equipotent (i.e., MICs within the range $2-8 \mu \mathrm{g} / \mathrm{mL}$ ).

Thus, when considering how hydrophobicity influences activity of the analogues against $E$. coli a clear pattern could not be discerned (see Figure S1): while the least hydrophobic compounds 2 and 3 ( peak elution at $35.7 \%$ and $35.6 \% \mathrm{MeCN}$, respectively) exhibited poorest antibacterial activity, the most potent peptidomimetics against E. coli (i.e., 7-9 and 12 with MICs in the range $2-4 \mu \mathrm{g} / \mathrm{mL}$ ) were not amongst the analogues with the highest hydrophobicity. Hence, no clear correlation between structural features and antibacterial potency was evident, since 7-9 and $\mathbf{1 2}$ differed with respect to both relative side-chain length of cationic and hydrophobic residues as well as the nature of peptoid residues. This indicated the existence of a hydrophobicity threshold for optimal activity against $E$. coli as previously found for end-group modified peptide/ $\beta$-peptoid hybrids [39].

Comparison of subgroup I peptidomimetics with those in subgroup III showed that their hydrophobicity was similar, but since all members of subgroup III were more potent, the hydrophobic nature of the peptoid residues appeared to be a more important contributing factor for high activity against $E$. coli than merely the overall hydrophobicity (see Figure S1). When comparing peptidomimetics from subgroups II and IV their hydrophobicity was similar, but higher than for subgroups I and III, which appeared to confer improved potency against $E$. coli. 
Two different strains of $P$. aeruginosa were included in the present study. No significant activity against these was observed for peptidomimetics in subgroup I, which displayed a generally low hydrophobicity, indicating that this property diminishes activity against $P$. aeruginosa. For the remaining subgroups, peptidomimetics with shorter cationic side chains exhibited higher activity against both strains of P. aeruginosa than peptidomimetics with longer cationic side chains. Generally, shortening of the cationic side chains by one methylene group conferred a two-fold increased potency. The compounds that proved most potent against P. aeruginosa contain hydrophobic peptoid residues, i.e., they belong to subgroups III and IV. Thus, a design with short-chain cationic amino acids and hydrophobic peptoid residues promotes antipseudomonal activity. These findings indicate that efficient membrane-disruptive interaction with $P$. aeruginosa requires that the peptidomimetics possess a hydrophobic "surface" comprised of the aromatic groups (partially) shielding the cationic side chains (see Figure S2). Previously, peptide/ $\beta$-peptoid analogues of peptidomimetics 9-16 were found to exhibit potent activity against $P$. aeruginosa (MIC values in the range of $2-8 \mu \mathrm{g} / \mathrm{mL}$ ) when the cationic side chains were short or when the hydrophobic side chains were extended $[38,42,55]$, thus supporting the present findings.

A putative explanation for the higher activity against E. coli as compared to the very low activity against K. pneumoniae is the higher overall content of anionic phospholipids in the cell membranes of E. coli that is likely to make this species more susceptible to the membrane-disruptive actions of these highly cationic peptidomimetics. Thus, in E. coli, cardiolipin (CL; with an overall charge of -2 ) and phosphatidylglycerol (PG; with a net charge of -1 ) comprise $5 \%$ and $15 \%$, respectively, of the total membrane phospholipids, while the content of the zwitterionic phosphatidylethanolamine (PE) is $80 \%$ [62]. In contrast, for K. pneumoniae the content of the negatively charged CL and PG is $6 \%$ and $5 \%$, respectively, resulting in an overall less negatively charged membrane, which may be anticipated to interact less efficiently with these peptidomimetics [63]. Similarly, the phospholipid content in the cell membrane of P. aeruginosa comprise $11 \% \mathrm{CL}$ and $21 \%$ PG, conferring a considerably higher negative charge to its membrane as compared to those of both E. coli and K. pneumoniae. Consequently, all differences in activity cannot readily be explained by their distinct phospholipid compositions alone. Yet, the outer membranes of P. aeruginosa, E. coli and K. pneumoniae differ somewhat with respect to the structure of lipid A that constitutes the inner part of lipopolysaccharide, which by far is the most abundant component of the outer leaflet. While lipid A in E. coli and K. pneumoniae have very similar structures (only differing in the position and length of a single fatty acid moiety), P. aeruginosa lipid A contains additional hydroxyl groups that enable increased hydrogen bonding between neighbouring lipid A molecules, thereby stabilising the outer membrane [64].

The antibacterial activity of the peptidomimetics was also tested against two Gram-positive bacteria (S. aureus and E. faecalis). Only peptidomimetics $\mathbf{5}$ and $\mathbf{6}$ showed moderate activity against $S$. aureus, whereas only $\mathbf{5}$ had weak activity against E. faecalis. Peptidomimetic $\mathbf{5}$ had the highest hydrophobicity of all analogues, while peptidomimetic 6 was amongst the most hydrophobic members, which is in accordance with previous studies, where a clear relationship was observed between hydrophobicity of peptoids and their activity against Gram-positive bacteria (in particular for S. aureus) [47,65]. Earlier studies have found similar trends for peptide/ $\beta$-peptoid hybrids, for which increased hydrophobicity could be correlated to higher activity against Gram-positive bacteria $[38,39,42]$.

\subsection{Effects of Relative Side-Chain Length and Flexibility on Mammalian Cell Viability}

The effects of the peptidomimetics on the viability of mammalian cells were tested against HepG2 cells and human red blood cells (see Table 2). In subgroup I, the combination of cationic peptoid residues and Phe resulted in a lower hydrophobicity than found for all other subgroups. Generally, the peptidomimetics in this subgroup exerted minimal effects on HepG2 cell viability, since all $\mathrm{IC}_{50}$ values were $1280 \mu \mathrm{g} / \mathrm{mL}$ or higher. Similarly, these compounds all exhibited weakly hemolytic properties (i.e., hemolysis below $10 \%$ at $800 \mu \mathrm{g} / \mathrm{mL}$ ). 
Table 2. Effects of peptidomimetics on mammalian cell viability.

\begin{tabular}{ccccccc}
\hline Subgroup & Cmpd & $\begin{array}{c}\text { Hydrophobicity } \\
\text { \% MeCN at elution }^{\mathbf{a}} \mathbf{)}\end{array}$ & $\begin{array}{c}\mathbf{I C}_{\mathbf{5 0}} \\
(\boldsymbol{\mu} \mathbf{g} \mathbf{m L})\end{array}$ & $\begin{array}{c}\text { Viability at } \\
\mathbf{1 2 8 0} \boldsymbol{\mu g} / \mathbf{m L}^{\mathbf{c}}\end{array}$ & $\begin{array}{c}\text { Hemolytic } \\
\text { Activity }^{\mathbf{d}}\end{array}$ & $\begin{array}{c}\text { Cell } \\
\text { Selectivity }^{\mathbf{e}}\end{array}$ \\
\hline I & $\mathbf{1}$ & $37.5 \%$ & 1280 & $49 \%$ & $7 \%$ & $160-320$ \\
I & $\mathbf{2}$ & $35.7 \%$ & $>1280$ & $62 \%$ & $5 \%$ & $>80$ \\
I & $\mathbf{3}$ & $35.6 \%$ & 1280 & $52 \%$ & $8 \%$ & $80-160$ \\
I & $\mathbf{4}$ & $36.6 \%$ & 1280 & $49 \%$ & $9 \%$ & $160-320$ \\
\hline II & $\mathbf{5}$ & $43.5 \%$ & 307 & - & $43 \%$ & 77 \\
II & $\mathbf{6}$ & $41.2 \%$ & 456 & - & $8 \%$ & 114 \\
II & $\mathbf{7}$ & $40.6 \%$ & 720 & - & $6 \%$ & $180-360$ \\
II & $\mathbf{8}$ & $40.9 \%$ & 266 & - & $9 \%$ & 133 \\
\hline III & $\mathbf{9}$ & $38.0 \%$ & 326 & - & $79 \%$ & $82-163$ \\
III & $\mathbf{1 0}$ & $37.2 \%$ & 923 & - & $10 \%$ & $115-231$ \\
III & $\mathbf{1 1}$ & $36.9 \%$ & $>1280$ & $76 \%$ & $10 \%$ & $>160$ \\
III & $\mathbf{1 2}$ & $38.0 \%$ & 1280 & $47 \%$ & $9 \%$ & 640 \\
\hline IV & $\mathbf{1 3}$ & $41.4 \%$ & 261 & - & $53 \%$ & 65 \\
IV & $\mathbf{1 4}$ & $40.5 \%$ & 684 & - & $11 \%$ & $86-171$ \\
IV & $\mathbf{1 5}$ & $40.5 \%$ & 595 & - & $8 \%$ & 149 \\
IV & $\mathbf{1 6}$ & $41.1 \%$ & 410 & - & $9 \%$ & 103 \\
\hline
\end{tabular}

${ }^{a}$ RP-HPLC gradient: $0 \rightarrow 60 \% \mathrm{~B}$ (during $10 \mathrm{~min}$ ). ${ }^{\mathrm{b}}$ Toxicity against HepG2 cells is given as $\mathrm{IC}_{50}$ value for inhibiting growth of HepG2 cells (assay was performed in two biological replicates each with three technical replicates). The highest concentration tested was $1280 \mu \mathrm{g} / \mathrm{mL}$. ${ }^{c}$ The viability of HepG2 cells at $1280 \mu \mathrm{g} / \mathrm{mL}$ is only given for compounds with an $\mathrm{IC}_{50}$ value of $1280 \mu \mathrm{g} / \mathrm{mL}$ or higher. ${ }^{\mathrm{d}}$ Percentage hemolysis in human red blood cells (RBCs) at $800 \mu \mathrm{g} / \mathrm{mL} .{ }^{\mathrm{e}}$ Cell selectivity was calculated as the ratio between $\mathrm{IC}_{50}$ for effect on HepG2 cell viability and MIC against E. coli.

For subgroup II (i.e., 5-8) there is a clear trend of an increasing effect on cell viability within the subseries NLys $\rightarrow$ NOrn $\rightarrow$ NDab (see Table 2.). For subgroup II further extension of the cationic side-chain length (from NLys in 7 to NhLys in 8) confers a slightly increased hydrophobicity due to incorporation of additional six methylene groups. This leads to a significantly increased effect of $\mathbf{8}$ on cell viability, corresponding to a ca. 2.7-fold lowering of the $\mathrm{IC}_{50}$ value as compared to that found for 7 . In subgroup II, the most hydrophobic analogue (i.e., 5) was the only representative giving rise to $>10 \%$ hemolysis at $800 \mu \mathrm{g} / \mathrm{mL}$.

Subgroup III (i.e., 9-12) also had relatively low hydrophobicity (see Table 2), and for 9-11 we observed a trend of increasing cationic side-chain length conferring gradually decreased hydrophobicity with an ensuing declining effect on HepG2 cell viability. However, even though $\mathbf{9}$ and $\mathbf{1 2}$ had similar hydrophobicity, only 9 (with a hydrophobic surface) had a pronounced effect on HepG2 cell viability and was the most hemolytic compound in the entire array $(79 \%$ hemolysis at $800 \mu \mathrm{g} / \mathrm{mL})$. Finally, subgroup IV peptidomimetics (i.e., 13-16) were found to possess relatively high hydrophobicity (see Table 2). However, no clear trends, attributable to cationic side-chain length or hydrophobicity, were observed with respect to their effect on HepG2 cell viability or hemolytic activity, except that peptidomimetic 13, displaying the shortest cationic side chain, also had pronounced hemolytic properties ( $53 \%$ hemolysis at $800 \mu \mathrm{g} / \mathrm{mL}$ ). The two peptidomimetics with highest hydrophobicity, namely 13 and 16, also exerted the strongest effect on HepG2 cell viability. In subgroups II and IV, the lowest $\mathrm{IC}_{50}$ values for HepG2 viability were seen for the two peptidomimetics with the shortest and longest cationic side chains, respectively. Also, in subgroups II-IV, the most distinct hemolytic properties were seen for the members displaying a hydrophobic "surface" comprised of the aromatic groups shielding the cationic side chains.

These findings regarding the relationships between hydrophobicity and effect on HepG2 cell viability, dicusssed above for the four subgroups of peptidomimetics, are depicted graphically below in Figure 3. 

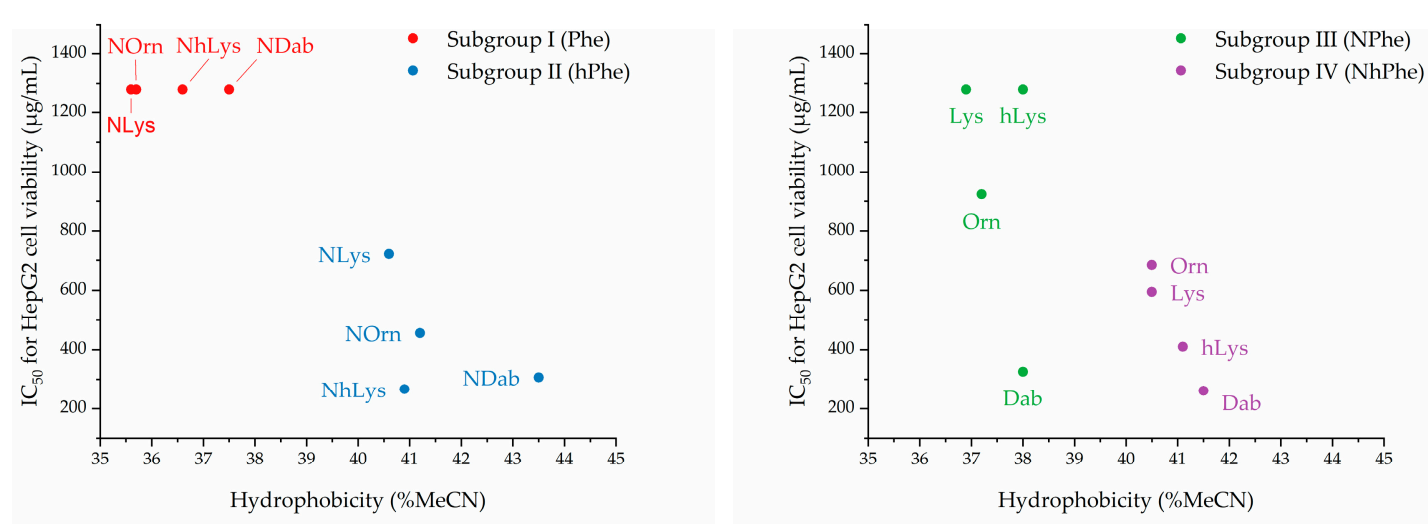

Figure 3. \%MeCN at RP-HPLC peak elution versus effect on HepG2 cell viability $\left(\mathrm{IC}_{50}\right)$.

The correlation between high hydrophobicity and loss of cell selectivity found for the present series of petidomimetics corroborates findings in a previous study on peptoid oligomers [32]. Here, a relatively small difference in hydrophobicity (also based on $\% \mathrm{MeCN}$ at peak elution) of the 12-mer $\mathrm{H}$-(NLys-Nspe-Nspe) $)_{4}-\mathrm{NH}_{2}$ and the corresponding 9-mer was observed (53.6\% MeCN versus 51.6\% $\mathrm{MeCN}$ ), and the concentration of these peptidomimetics resulting in 10\% hemolysis (of human red blood cells) were $9.1 \mu \mathrm{M}$ and $119.5 \mu \mathrm{M}$, respectively. Also, two 12-mer analogues with further increased hydrophobicity (due to incorporation of Nspe-derived residues with either a $\mathrm{Me}$ or $\mathrm{Cl}$ substituent in the 4-position; peak elution at $61.1 \% \mathrm{MeCN}$ and $64.1 \% \mathrm{MeCN}$, respectively) proved to be exceedingly hemolytic with $10 \%$ hemolysis reached below $6.25 \mu \mathrm{M}$ [32]. Also, moieties within a wide range of polarity have been introduced at the $\mathrm{N}$-terminus of an $\alpha$-peptide/ $\beta$-peptoid template in order to evaluate the ensuing effects on the activity profile of the resulting analogues [39]. Thus, analogues with aliphatic or aromatic end-group modifications showed increased antibacterial activity over the template. However, even though these compounds exhibited similar effects on the viability of NIH 3T3 (fibroblast cells, $\mathrm{IC}_{50}$ values in the range 35-67 $\mu \mathrm{M}$ ) and HUVEC cells (human umbilical vein endothelial cells, $\mathrm{IC}_{50}$ values of $\sim 150 \mu \mathrm{M}$ ) their hemolytic properties differed considerably (i.e., $50 \%$ hemolysis was reached between $9 \mu \mathrm{M}$ and $602 \mu \mathrm{M}$ ) as did their hydrophobicity ( peak elution between $48.8 \%$ and $54.3 \% \mathrm{MeCN}$ ). Two compounds eluting below 50\% MeCN displayed the lowest effect on mammalian cell viability, and in particular, they exhibited significantly reduced hemolytic properties. Collectively, these findings strongly corroborate the hypothesis that, within a series of closely related compounds, there exists a threshold for acceptable maximal hydrophobicity, beyond which cell selectivity is lost completely.

In several studies, two hydrophobicity thresholds have been identified for both AMPs and antibacterial peptidomimetics $[36,41,65-70]$. Thus, the hydrophobicity of an AMP or peptidomimetic must exceed the lower threshold in order to possess potent antibacterial activity. However, when the higher threshold is surpassed the compound will lose selectivity toward bacteria over mammalian cells. In the present study, a lower hydrophobicity threshold for activity against susceptible Gram-negative bacteria (i.e., E. coli and P. aeruginosa) could not be identified for E. coli, whereas against P. aeruginosa, only peptidomimetics with a hydrophobicity above $\sim 37 \% \mathrm{MeCN}$ proved active. However, for P. aeruginosa, this was not the only criteria that should be fulfilled, since peptidomimetics with shorter cationic side chains proved most active, regardless of hydrophobicity.

For subgroups I and III, which both contained cationic peptoid residues and hydrophobic amino acid residues, analogues with a low hydrophobicity ( $\sim$ to peak elution below $\sim 38 \% \mathrm{MeCN}$ ) exerted a negligible effect on HepG2 cell viability when excluding peptidomimetic 9. Noticeably, three out of four peptidomimetics containing the shortest cationic side chains (i.e., 5, 9, and 13) had the highest hydrophobicity in their subgroup and showed pronounced hemolysis in the range $43-79 \%$ at $800 \mu \mathrm{g} / \mathrm{mL}$. Interestingly, although 1 and 9 had very similar hydrophobicity ( peak elution at $37.5 \%$ and $38.0 \%$ $\mathrm{MeCN}$, respectively) they possess quite different hemolytic properties. This deviation from the common 
trend may be explained by the fact that 1 contains cationic peptoid residues, while the very hemolytic 9 display hydrophobic peptoid residues. Molecular modelling have suggested that peptoids have a greater diversity of conformational states than peptides [11], which means that the combination of short cationic side chains and flexible hydrophobic side chains are expected to interact more favorably with the cell membranes of red blood cells, thus conferring hemolytic properties even below the critical hydrophobicity threshold for antibacterial activity.

\section{Materials and Methods}

\subsection{General Information}

Starting materials and solvents were purchased from commercial suppliers (Iris Biotech, Markredwitz, Germany; Fluorochem, Hadfield, United Kingdom; and Merck, Darmstadt, Germany) and used without further purification. Water used for analytical and preparative high-performance liquid chromatography (HPLC) was filtered through a $0.22-\mu \mathrm{m}$ Millipore membrane filter. Purity and retention time of each peptidomimetic were determined by analytical UHPLC by using a Phenomenex Luna C18(2) HST column (100 mm $\times 3 \mathrm{~mm}$; particle size: $2.5 \mu \mathrm{m}$; pore size: $100 \AA)$ on a Shimadzu Prominence and Shimadzu Nexera system using an aqueous acetonitrile (MeCN) gradient with $0.1 \%$ trifluoroacetic acid (TFA) added (eluent A: 5:95 MeCN- $\mathrm{H}_{2} \mathrm{O}+0.1 \%$ TFA, eluent B: 95:5 $\mathrm{MeCN}-\mathrm{H}_{2} \mathrm{O}+0.1 \%$ TFA); a flow rate of $0.5 \mathrm{~mL} / \mathrm{min}$ was used. For elution of peptidomimetics, a linear gradient of $0 \%$ to $60 \% \mathrm{~B}$ during $10 \mathrm{~min}$ was used with UV detection at $\lambda=220 \mathrm{~nm}$. All tested compounds had a purity of at least $97 \%$. For each peptidomimetic, the percentage of MeCN at peak elution was calculated from the retention time by using the following formula:

$$
\% \mathrm{MeCN}=0.95\left(0.6 \frac{R_{t}}{10 \mathrm{~min} .}\right)+0.05\left(1-0.6 \frac{R_{t}}{10 \mathrm{~min} .}\right)
$$

Preparative HPLC was performed by using a Phenomenex Luna C18(2) column $(250 \times 21.2 \mathrm{~mm}$; particle size: $5 \mu \mathrm{m}$ ) on a Shimadzu Prominence system using the same eluents as for analytical HPLC. Elution was performed with a linear gradient of $0 \%$ to $40 \%$ B during $20 \mathrm{~min}$ at a flow rate of $20 \mathrm{~mL} / \mathrm{min}$ with UV detection at $\lambda=220 \mathrm{~nm}$. High-resolution mass spectrometry (HRMS) spectra were obtained by using a Bruker Solarix XR MS detector.

\subsection{Building Block Synthesis}

3.2.1. Synthesis of $N-(((9 H-$ fluoren-9-yl)methoxy)carbonyl)-N-(5-((tertbutoxycarbonyl)amino)ethyl)glycine [Fmoc-NDab(Boc)-OH, 17]

Tert-butyl (5-aminoethyl)carbamate (11.7 g) was dissolved in THF (110 mL), and then $\mathrm{Et}_{3} \mathrm{~N}$ (16 mL, 3.0 equiv) was added to the solution under stirring. The mixture was kept at room temperature (rt) for $10 \mathrm{~min}$. Ethyl bromoacetate $(12.24 \mathrm{~mL}, 1$ equiv) was dissolved in THF (100 mL) and added dropwise to the solution under stirring. The mixture was kept at $\mathrm{rt}$ for $16 \mathrm{~h}$. The mixture was concentrated in vacuo, and then the residue redissolved in $\mathrm{Et}_{2} \mathrm{O}(300 \mathrm{~mL})$ and filtered. The filtrate was concentrated in vacuo to afford the intermediate ethyl ester $(17.65 \mathrm{~g})$ as a colourless oil, which was dissolved in dioxane $(100 \mathrm{~mL})$ and $\mathrm{MeOH}(40 \mathrm{~mL})$. Then, $4 \mathrm{M} \mathrm{NaOH}(18 \mathrm{~mL})$ was added dropwise under stirring. The mixture was kept at $\mathrm{rt}$ for $1 \mathrm{~h}$, then concentrated in vacuo, and the residue redissolved in $\mathrm{H}_{2} \mathrm{O}$ (100 mL). Fmoc-OSu (23.69 g, 1 equiv) was dissolved in warm (45 $\left.{ }^{\circ} \mathrm{C}\right) \mathrm{MeCN}(170 \mathrm{~mL})$ and added dropwise to the mixture under stirring. The mixture was kept at $\mathrm{rt}$ for $16 \mathrm{~h}$, then concentrated in vacuo until it turned turbid. Then EtOAc $(300 \mathrm{~mL})$ was added, and the resulting mixture was washed with $10 \%$ citric acid $(400 \mathrm{~mL})$. The aqueous phase was extracted with EtOAc $(2 \times 150 \mathrm{~mL})$, and the combined organic phases were washed with $\mathrm{H}_{2} \mathrm{O}(3 \times 250 \mathrm{~mL})$, and brine $(250 \mathrm{~mL})$. The organic phase was extracted with $10 \% \mathrm{NaHCO}_{3}-10 \% \mathrm{Na}_{2} \mathrm{CO}_{3}$-dioxane 3:3:2 $(4 \times 400 \mathrm{~mL})$. The combined aqueous phases were adjusted to $\mathrm{pH}$ 2-3 with $4 \mathrm{M} \mathrm{HCl}$, extracted with EtOAc $(150 \mathrm{~mL})$, then combined, dried over $\mathrm{Na}_{2} \mathrm{SO}_{4}$ and concentrated in vacuo. The resulting solid was recrystallised from EtOAc $(200 \mathrm{~mL})$ and 
heptane $(800 \mathrm{~mL})$ to afford building block $17(25.0 \mathrm{~g}, 77.6 \%)$ as a white solid; $\mathrm{t}_{\mathrm{R}}=6.53 \mathrm{~min}$. (gradient $30-100 \%$ B during 10 min). HRMS: calcd for $\mathrm{C}_{24} \mathrm{H}_{28} \mathrm{~N}_{2} \mathrm{O}_{6}[\mathrm{M}+\mathrm{Na}]^{+} 463.18396$, found 463.18550; $\Delta \mathrm{M}=3.3 \mathrm{ppm} .{ }^{1} \mathrm{H}$ NMR (600 MHz, methanol- $\left.d_{4}\right) \delta 7.79$ (m, 2H, ArH-Fmoc), 7.61 (m, 2H, ArH-Fmoc), 7.39 (m, 2H, ArH-Fmoc), 7.31 (m, 2H, ArH-Fmoc), 4.39 (m, 2H, CH 2 -Fmoc), 4.24 (m, 1H, CH-Fmoc), $\left.3.99\left(\mathrm{~s}, 2 \mathrm{H}, \mathrm{N}-\mathrm{CH}_{2}-\mathrm{C}=\mathrm{O}\right)\right), 3.43-3.25\left(\mathrm{~m}, 2 \mathrm{H}, \mathrm{CH}_{2}-\mathrm{CH}_{2}-\mathrm{N}\right), 3.03\left(\mathrm{t}, \mathrm{J}=6.2 \mathrm{~Hz}, 2 \mathrm{H}, \mathrm{N}-\mathrm{CH}_{2}-\mathrm{CH}_{2}\right), 1.40$ (s, 9H, $\mathrm{CH}_{3}$-Boc). ${ }^{13} \mathrm{C}$ NMR $\left(151 \mathrm{MHz}\right.$, methanol- $\left.d_{4}\right) \delta 171.73,156.77,156.66,143.85,141.20,127.43$, $126.85,124.68,119.55,78.83,67.84,49.09,48.66,47.00,38.27,27.35$.

3.2.2. Synthesis of $N-(((9 H-$ fluoren-9-yl)methoxy)carbonyl)-N-(5-((tertbutoxycarbonyl)amino)propyl)glycine [Fmoc-NOrn(Boc)-OH, 18]

Fmoc-NOrn(Boc)-OH (18) was prepared, analogously to the preparation of $\mathbf{1 7}$, from tert-butyl (5-aminopropyl)carbamate (10.0 g). Crystallisation from EtOAc-heptane afforded building block 18 $(18.6 \mathrm{~g}, 61 \%)$ as a white solid; $t_{\mathrm{R}}=6.72 \mathrm{~min}$. (gradient $30-100 \% \mathrm{~B}$ during $10 \mathrm{~min}$ ). HRMS: calcd for $\mathrm{C}_{25} \mathrm{H}_{30} \mathrm{~N}_{2} \mathrm{O}_{6}[\mathrm{M}+\mathrm{Na}]^{+}$477.19961, found 477.20298; $\Delta \mathrm{M}=7.1 \mathrm{ppm} .{ }^{1} \mathrm{H}$ NMR $\left(600 \mathrm{MHz}\right.$, methanol- $\left.\mathrm{d}_{4}\right)$ $\delta 7.79$ (m, 2H, ArH-Fmoc), 7.60 (m, 2H, ArH-Fmoc), 7.38 (q, J = 7.1 Hz, 2H, ArH-Fmoc), 7.31 (m, 2H, ArH-Fmoc), 4.44 (m, 2H, CH - -Fmoc), 4.22 (m, 1H, CH-Fmoc), 3.92 (d, J = 4.2 Hz, 2H, N-CH $-\mathrm{C}=\mathrm{O}$ )), 3.34, 3.10 (two m, 2H, N-CH $-\mathrm{CH}_{2}$ ), 3.03, 2.82 (two m, 2H, $\mathrm{CH}_{2}-\mathrm{CH}_{2}-\mathrm{CH}_{2}$ ), 1.67 (p, J = 6.8 Hz, $2 \mathrm{H}$, $\left.\mathrm{CH}_{2}-\mathrm{CH}_{2}-\mathrm{N}\right), 1.41$ (s, 9H, $\mathrm{CH}_{3}$-Boc). ${ }^{13} \mathrm{C}$ NMR $\left(151 \mathrm{MHz}\right.$, methanol-d $\left.{ }_{4}\right) \delta 171.63,157.02,156.63,143.88$, $141.25,127.40,126.83,124.57,119.55,67.39,48.58,47.05,45.94,37.32,27.83,27.36$.

3.2.3. Synthesis of $N-(((9 H-$ fluoren-9-yl)methoxy)carbonyl)- $N-(5-(($ tertbutoxycarbonyl)amino)butyl)glycine [Fmoc-NLys(Boc)-OH, 19]

Fmoc-NLys(Boc)-OH (19) was prepared, analogously to to the preparation of $\mathbf{1 7}$, from tert-butyl (5-aminobutyl)carbamate ( $24.9 \mathrm{~g})$. Crystallisation from EtOAc-heptane afforded building block 19 $(39.9 \mathrm{~g}, 43 \%)$ as a white solid; $\mathrm{t}_{\mathrm{R}}=6.94 \mathrm{~min}$. (gradient $30-100 \% \mathrm{~B}$ during $10 \mathrm{~min}$ ). HRMS: calcd for $\mathrm{C}_{26} \mathrm{H}_{32} \mathrm{~N}_{2} \mathrm{O}_{6}[\mathrm{M}+\mathrm{Na}]^{+} 491.21526$, found $491.21664 ; \Delta \mathrm{M}=2.8 \mathrm{ppm} .{ }^{1} \mathrm{H}$ NMR $\left(600 \mathrm{MHz}\right.$, methanol- $\left.d_{4}\right)$ $\delta 7.80$ (m, 2H, ArH-Fmoc), 7.60 (m, 2H, ArH-Fmoc), 7.38 (m, 2H, ArH-Fmoc), 7.31 (m, 2H, ArH-Fmoc), $\left.4.46\left(\mathrm{~m}, 2 \mathrm{H}, \mathrm{CH}_{2}-\mathrm{Fmoc}\right), 4.22(\mathrm{~m}, 1 \mathrm{H}, \mathrm{CH}-\mathrm{Fmoc}), 3.90\left(\mathrm{~m}, 2 \mathrm{H}, \mathrm{N}-\mathrm{CH}_{2}-\mathrm{C}=\mathrm{O}\right)\right), 3.35-3.27(\mathrm{~m}, 2 \mathrm{H}$, $\mathrm{CH}_{2}-\mathrm{CH}_{2}-\mathrm{N}$ ), 3.04, 2.90 (two t, $J=6.8 \mathrm{~Hz}, 2 \mathrm{H}, \mathrm{N}-\mathrm{CH}_{2}-\mathrm{CH}_{2}$ ), 3.01, 1.19 (two $\mathrm{m}, 2 \mathrm{H}, \mathrm{N}-\mathrm{CH}_{2}-\mathrm{CH}_{2}-\mathrm{CH}_{2}$ ), $1.52,1.45\left(\mathrm{q}, J=7.4 \mathrm{~Hz}, 1 \mathrm{H}, \mathrm{CH}_{2}-\mathrm{CH}_{2}-\mathrm{CH}_{2}-\mathrm{N}\right), 1.43\left(\mathrm{~s}, 9 \mathrm{H}, \mathrm{CH}_{3}-\mathrm{Boc}\right) .{ }^{13} \mathrm{C}$ NMR $\left(151 \mathrm{MHz}\right.$, methanol-d $\left.d_{4}\right)$ $\delta 171.56,156.75,156.53,143.83,141.35,127.44,126.84,124.70,119.60,78.46,66.85,48.08,47.92,47.82$, $47.08,39.54,27.40,26.66,24.67$.

3.2.4. Synthesis of $N-(((9 H-$ fluoren-9-yl)methoxy)carbonyl)- $N-(5-(($ tertbutoxycarbonyl)amino)pentyl)glycine [Fmoc-NhLys(Boc)-OH, 20]

Fmoc-NhLys(Boc)-OH (20) was prepared, analogously to to the preparation of $\mathbf{1 7}$, from tert-butyl (5-aminopentyl)carbamate $(5.0 \mathrm{~g})$. Crystallisation from EtOAc-heptane afforded building block 20 $(5.4 \mathrm{~g}, 45 \%)$ as a white solid; $t_{\mathrm{R}}=7.27 \mathrm{~min}$. (gradient $30-100 \% \mathrm{~B}$ during $10 \mathrm{~min}$ ). HRMS: calcd for $\mathrm{C}_{27} \mathrm{H}_{34} \mathrm{~N}_{2} \mathrm{O}_{6}[\mathrm{M}+\mathrm{Na}]^{+} 505.23091$, found 505.23220; $\Delta \mathrm{M}=2.6$ ppm. ${ }^{1} \mathrm{H} \mathrm{NMR}\left(600 \mathrm{MHz}, \mathrm{CDCl}_{3}\right) \delta 7.74$ (m, 2H, ArH-Fmoc), 7.55 (m, 2H, ArH-Fmoc), 7.37 (m, 2H, ArH-Fmoc), 7.29 (m, 2H, ArH-Fmoc), 4.48 $\left(\mathrm{m}, 2 \mathrm{H}, \mathrm{CH}_{2}-\mathrm{Fmoc}\right), 4.21$ (m, 1H, CH-Fmoc), $3.93\left(\mathrm{~m}, 2 \mathrm{H}, \mathrm{N}-\mathrm{CH}_{2}-\mathrm{C}(\mathrm{O})\right.$ ), 3.31, 3.04 (two t, $J=7.3 \mathrm{~Hz}, 2 \mathrm{H}$, $\left.\mathrm{CH}_{2}-\mathrm{CH}_{2}-\mathrm{N}\right), 3.08\left(\mathrm{q}, J=8.8,8.2 \mathrm{~Hz}, 2 \mathrm{H}, \mathrm{N}-\mathrm{CH}_{2}-\mathrm{CH}_{2}\right), 1.52\left(\mathrm{p}, J=7.5 \mathrm{~Hz}, 1 \mathrm{H}, \mathrm{CH}_{2}-\mathrm{CH}_{2}-\mathrm{CH}_{2}-\mathrm{N}\right), 1.46(\mathrm{~s}$, 9H, $\left.\mathrm{CH}_{3}-\mathrm{Boc}\right), 1.36\left(\mathrm{p}, J=7.4 \mathrm{~Hz}, 2 \mathrm{H}, \mathrm{N}-\mathrm{CH}_{2}-\mathrm{CH}_{2}-\mathrm{CH}_{2}\right), 1.30\left(\mathrm{p}, J=7.7 \mathrm{~Hz}, 2 \mathrm{H}, \mathrm{CH}_{2}-\mathrm{CH}_{2}-\mathrm{CH}_{2}-\mathrm{N}\right), 1.27$, 1.09 (two m, 2H, $\mathrm{CH}_{2}-\mathrm{CH}_{2}-\mathrm{CH}_{2}-\mathrm{CH}_{2}-\mathrm{CH}_{2}$ ). ${ }^{13} \mathrm{C} \mathrm{NMR}\left(151 \mathrm{MHz}, \mathrm{CDCl}_{3}\right.$ ) $\delta 173.69,156.79,156.14,144.05$, $141.48,127.79,127.20,124.98,120.06,79.54,67.81,48.82,48.66,47.40,40.64,29.71,28.56,27.76,23.89$.

\subsubsection{Synthesis of $N-(((9 H-$ fluoren-9-yl)methoxy)carbonyl)- $N$-benzylglycine [Fmoc-NPhe-OH, 21]}

Fmoc-NPhe-OH (21) was prepared, analogously to the preparation of $\mathbf{1 7}$, from benzylamine $(14.0 \mathrm{~g})$. Crystallisation from EtOAc-heptane afforded building block $21(24.5 \mathrm{~g}, 48.3 \%) ; \mathrm{t}_{\mathrm{R}}=7.18 \mathrm{~min}$. (gradient 30-100\% B during $10 \mathrm{~min}$ ) HRMS: calcd for $\mathrm{C}_{24} \mathrm{H}_{21} \mathrm{NO}_{4}[\mathrm{M}+\mathrm{Na}]^{+} 410.13628$, found 410.13852; 
$\Delta \mathrm{M}=5.5 \mathrm{ppm} .{ }^{1} \mathrm{H}$ NMR $\left(600 \mathrm{MHz}\right.$, methanol- $\left.\mathrm{d}_{4}\right) \delta 7.76(\mathrm{~m}, 2 \mathrm{H}, \operatorname{ArH}-\mathrm{Fmoc}), 7.62-7.48(\mathrm{~m}, 2 \mathrm{H}$, $\mathrm{ArH}-\mathrm{Ph}$ ), 7.37 (m, 2H, ArH-Fmoc), 7.30 (m, 2H, ArH-Fmoc), 7.28-7.24 (m, 2H, ArH-Ph), 7.24-7.15 (m, 2H, ArH-Fmoc), 7.00-6.96 (m, 1H, ArH-Ph), 4.51, 4.33 (two s, 2H, N-CH $-\mathrm{C}=\mathrm{O}$ ), 4.51 (m, 2H, ArH-Fmoc), 4.22 ( $\mathrm{t}, J=6.1 \mathrm{~Hz}, 1 \mathrm{H}, \mathrm{CH}$-Fmoc), 3.87, 3.75 (two s, $2 \mathrm{H}, \mathrm{CH}_{2}$-Ph). ${ }^{13} \mathrm{C} \mathrm{NMR}(151 \mathrm{MHz}$, methanol- $\left.\mathrm{d}_{4}\right) \delta 171.28,156.83,143.80,141.29,136.84,128.29,127.53,127.43,127.37,127.24,127.13,126.80$, $126.79,124.58,119.56,67.51,50.91,46.98,46.85$.

3.2.6. Synthesis of $\mathrm{N}-(((9 \mathrm{H}$-fluoren-9-yl)methoxy)carbonyl)- $\mathrm{N}$-phenethylglycine [Fmoc-NhPhe-OH, 22]

Phenethylamine $(20.8 \mathrm{~mL})$ was dissolved in THF $(75 \mathrm{~mL})$. Then $\mathrm{Et}_{3} \mathrm{~N}(69 \mathrm{~mL}, 3.0$ equiv) was added to the solution. Tert-butyl bromoacetate ( $32.2 \mathrm{~g}$, 1 equiv) was dissolved in THF (75 mL) and added dropwise to the solution under stirring. The mixture was kept at $\mathrm{rt}$ for $16 \mathrm{~h}$. The mixture was filtered, the filtrate was concentrated in vacuo, and the residue was redissolved in $\mathrm{CH}_{2} \mathrm{Cl}_{2}$ (50 mL). The solution was loaded onto a VLC column (height, $7.5 \mathrm{~cm}$; diameter, $12 \mathrm{~cm}$; column material: 15-40 $\mu \mathrm{m}$ silica gel, column pretreated with heptane). Gradient elution was carried out with heptane followed by $\mathrm{CH}_{2} \mathrm{Cl}_{2}-\mathrm{MeOH}$ 100:1 and $\mathrm{CH}_{2} \mathrm{Cl}_{2}-\mathrm{MeOH}$ 50:10. The appropriate fractions were concentrated in vacuo to yield the intermediate tert-butyl ester $(31.8 \mathrm{~g}, 82 \%)$ as a yellow oil, which was dissolved in $\mathrm{CH}_{2} \mathrm{Cl}_{2}(120 \mathrm{~mL})$, and then TFA $(280 \mathrm{~mL})$ was added slowly to the solution under stirring. The mixture was kept at $\mathrm{rt}$ for $4 \mathrm{~h}$ and then concentrated in vacuo. The residue was dissolved in toluene $(100 \mathrm{~mL})$ and concentrated in vacuo. This was repeated twice to give the crude acid $(39.76 \mathrm{~g})$ as a yellow solid, which was dissolved in dioxane $(400 \mathrm{~mL})$ and $10 \% \mathrm{Na}_{2} \mathrm{CO}_{3}(800 \mathrm{~mL})$. Then, $\mathrm{Fmoc}-\mathrm{Cl}$ ( $72.6 \mathrm{~g}$, 1.7 equiv) dissolved in dioxane $(400 \mathrm{~mL})$ was added dropwise under stirring at $0{ }^{\circ} \mathrm{C}$. The mixture was then kept at $\mathrm{rt}$ for $16 \mathrm{~h}$. The mixture was adjusted to $\mathrm{pH} 10$ by adding $10 \% \mathrm{Na}_{2} \mathrm{CO}_{3}(200 \mathrm{~mL})$ and split into four portions $(\sim 450 \mathrm{~mL})$. Each portion was diluted with $\mathrm{H}_{2} \mathrm{O}(500 \mathrm{~mL})$, washed with $\mathrm{Et}_{2} \mathrm{O}(900 \mathrm{~mL})$, and filtered. The filtrate was adjusted to $\mathrm{pH} 1$ by adding concentrated $\mathrm{HCl}(20 \mathrm{~mL})$, and then extracted with EtOAc $(900 \mathrm{~mL})$. The combined organic phases were concentrated in vacuo to yield the crude product as a solid $(55.8 \mathrm{~g}, 85 \%)$ which was dissolved in $\mathrm{CH}_{2} \mathrm{Cl}_{2}(100 \mathrm{~mL})$ and loaded onto a VLC column (height, $11.5 \mathrm{~cm}$; diameter, $12.0 \mathrm{~cm}$; column material: 15-40 $\mu \mathrm{m}$ silica gel, column pretreated with heptane). Gradient elution was carried out with heptane followed by heptane-EtOAc 4:1 and heptane-EtOAc 1:1. The appropriate fractions were concentrated in vacuo to yield building block $22(40.6 \mathrm{~g}, 62 \%)$ as a white solid; $t_{\mathrm{R}}=7.50 \mathrm{~min}$ (gradient 30-100\% B during $10 \mathrm{~min}$ ). HRMS: calcd for $\mathrm{C}_{25} \mathrm{H}_{23} \mathrm{NO}_{3}[\mathrm{M}+\mathrm{Na}]^{+} 424.15193$, found $424.15548 ; \Delta \mathrm{M}=8.4 \mathrm{ppm} .{ }^{1} \mathrm{H} \mathrm{NMR}\left(600 \mathrm{MHz}\right.$, methanol- $\left.d_{4}\right)$ $\delta 7.81-7.75$ (m, 2H, ArH-Fmoc), 7.59 (m, 2H, ArH-Fmoc), 7.38 (m, 2H, ArH-Fmoc), 7.31 (m, 2H, ArH-Fmoc), 7.23 (m, 2H, ArH-Ph), 7.19-7.13 (m, 2H, ArH-Ph), 6.92-6.87 (m, 1H, ArH-Ph), 4.47 (m, $2 \mathrm{H}, \mathrm{CH}_{2}$-Fmoc), 4.18 (dd, $\left.J=6.5,5.6 \mathrm{~Hz}, 1 \mathrm{H}, \mathrm{CH}-\mathrm{Fmoc}\right), 3.78\left(\mathrm{~m}, 2 \mathrm{H}, \mathrm{N}-\mathrm{CH}_{2}-\mathrm{C}=\mathrm{O}\right), 3.35(\mathrm{~m}, 2 \mathrm{H}$, $\left.\mathrm{N}-\mathrm{CH}_{2}-\mathrm{CH}_{2}\right), 2.62\left(\mathrm{~m}, 2 \mathrm{H}, \mathrm{CH}_{2}-\mathrm{CH}_{2}-\mathrm{Ph}\right) .{ }^{13} \mathrm{C} \mathrm{NMR}\left(151 \mathrm{MHz}\right.$, methanol- $\left.d_{4}\right) \delta 171.59,156.53,143.93$, $141.39,138.81,128.49,128.07,127.39,126.81,125.90,124.50,119.59,66.54,49.86,48.65,47.05,33.96$.

\subsection{General Protocol for Manual Synthesis of Peptidomimetics}

Peptidomimetics 4-10, 12, 13, and 16 were prepared manually as previously described [38]. In brief, H-Rink-Amide ChemMatrix resin (PCAS BioMatrix Inc., Saint-Jean-sur-Richelieu, QC, Canada; loading $0.52 \mathrm{mmol} / \mathrm{g}, 0.05 \mathrm{mmol})$ and Teflon vessels $(10 \mathrm{~mL}$; fitted with a polypropylene filter) were used. Coupling conditions used for Fmoc-protected amino acid and peptoid building blocks: 3.0 equiv building block, 3.0 equiv $N, N^{\prime}$-diisopropylcarbodiimide (DIC), and 3.0 equiv ethyl (hydroxyimino)cyanoacetate (OxymaPure ${ }^{\circledR}$ ) ( $>1 \mathrm{~h}$ under shaking at $40{ }^{\circ} \mathrm{C}$; amino acid building blocks were coupled twice to ensure complete conversion of resin-bound peptoid secondary amines). Fmoc deprotection conditions: $20 \%$ piperidine in DMF $(2 \times 10 \mathrm{~min}$, each time with $5 \mathrm{~mL}$ under shaking at $\left.40{ }^{\circ} \mathrm{C}\right)$. Washing conditions: $\mathrm{DMF}, \mathrm{MeOH}$, and $\mathrm{CH}_{2} \mathrm{Cl}_{2}(3 \times 3 \mathrm{~min}$, each time with $5 \mathrm{~mL}$ under shaking at $40^{\circ} \mathrm{C}$ ). Capping was applied after loading, and after all couplings with amino acid building blocks (except the last one): $\mathrm{Ac}_{2} \mathrm{O}$-DIPEA-NMP 1:2:3 (5 mL for $10 \mathrm{~min}$ under shaking at $40{ }^{\circ} \mathrm{C}$ ). 
Cleavage and side-chain deprotection were performed with TFA- $\mathrm{H}_{2} \mathrm{O}-\mathrm{CH}_{2} \mathrm{Cl}_{2}(95: 2.5: 2.5 ; 2 \times 1 \mathrm{~h}$, each with $5 \mathrm{~mL}$ under shaking at rt). The filtrates were collected, and the resin was further eluted with TFA ( $2 \mathrm{~mL})$ and $\mathrm{CH}_{2} \mathrm{Cl}_{2}(2 \mathrm{~mL})$. The combined filtrates were concentrated in vacuo and co-evaporated with toluene $(3 \times 5 \mathrm{~mL})$. The crude product was purified by preparative HPLC, and the appropriate fractions were concentrated in vacuo and lyophilised. Identity was verified by HRMS, and purity (>97\%) was determined by analytical UHPLC.

\subsection{General Protocol for Microwave-Assisted Automated Synthesis of Peptidomimetics}

Peptidomimetics 1-3, 11, 14, and 15 were prepared by automated microwave (MW)-assisted Fmoc-based SPPS on a CEM ${ }^{\mathrm{TM}}$ Liberty microwave peptide synthesiser. H-Rink-Amide ChemMatrix ${ }^{\circledR}$ resin (PCAS Bio-Matrix Inc., Saint-Jean-sur-Richelieu, QC, Canada; loading $0.52 \mathrm{mmolg}^{-1}, 0.1 \mathrm{mmol}$ ) was used. Fmoc (9-fluorenylmethyloxycarbonyl) deprotection conditions: excess 20\% piperidine in DMF, initially $75{ }^{\circ} \mathrm{C}(\mathrm{MW})$ for $30 \mathrm{~s}$, subsequently $75{ }^{\circ} \mathrm{C}(\mathrm{MW})$ for $180 \mathrm{~s}$. Coupling conditions: 5.0 equiv of building block, 5.0 equiv DIC, and 5.0 equiv OxymaPure ${ }^{\circledR}, \mathrm{DMF}, 75^{\circ} \mathrm{C}(\mathrm{MW})$ for $15 \mathrm{~min}$. The resin was transferred to a Teflon vessel fitted with a polypropylene filter by using DMF and $\mathrm{CH}_{2} \mathrm{Cl}_{2}$. Upon draining, the resin was washed with $\mathrm{DMF}, \mathrm{MeOH}$, and $\mathrm{CH}_{2} \mathrm{Cl}_{2}(3 \times 3 \mathrm{~min}$, each time with $5 \mathrm{~mL}$ under shaking at $\mathrm{rt}$ ). Cleavage and side-chain deprotection followed by purification were performed as described above for manual synthesis of peptidomimetics.

\subsection{Determination of Minimum Inhibitory Concentration}

MIC values were evaluated by using the modified Hancock lab protocol [71] in non-binding polystyrene microtitre plates, with bacterial suspensions of $\sim 2 \times 10^{5} \mathrm{CFU} / \mathrm{mL}$ in Mueller-Hinton broth (Difco, Sparks MD, USA), with $\mathrm{Mg}^{2+}$ and $\mathrm{Ca}^{2+}$ concentrations of $4 \mathrm{mg} / \mathrm{L}$ each. The compounds were dissolved in $\mathrm{H}_{2} \mathrm{O}$ and diluted in $0.01 \%$ acetic acid, $0.2 \%$ BSA (final concentration). Aliquots of $11 \mu \mathrm{L}$ of $10 \times$ test compounds were then transferred to the appropriate wells with bacterial suspensions. For preparation and transfer of the solutions of the compounds, low-binding sterile tubes and tips (Axygen, Union City CA, USA) were used. After $20 \mathrm{~h}$ incubation of covered plates at $35^{\circ} \mathrm{C}\left( \pm 2{ }^{\circ} \mathrm{C}\right)$ with circular shaking at $220 \mathrm{rpm}$, the MICs were read. The antibacterial activity of peptidomimetics was tested against E. coli ATCC 25922, K. pneumoniae ATCC 13883, P. aeruginosa ATCC 27853, P. aeruginosa PAO1, A. baumannii ATCC 19606, S. aureus ATCC 29213, and E. faecalis ATCC 29212.

\subsection{Determination of Hemolytic Activity}

The lysis of human red blood cells was measured as previously described [15], with modifications. In brief, freshly drawn human red blood cells (hRBCs) were washed three times with PBS buffer and centrifuged two times for $5 \mathrm{~min}$ at $2500 \mathrm{rpm}$. A two-fold serial dilution of peptidomimetics in PBS buffer was added to each well in a sterile polypropylene V-bottom 96-well plate to the total volume of $75 \mu \mathrm{L}$. A $0.5 \% v / v$ hRBC suspension (75 $\mu \mathrm{L}$ in PBS buffer) was added to each well to reach a final volume of $150 \mu \mathrm{L}$ in each well. The plate was incubated $\left(37^{\circ} \mathrm{C}\right)$ for $60 \mathrm{~min}$, and then the cells were subsequently pelleted by centrifugation at $1000 \mathrm{rpm}$ for $5 \mathrm{~min}$. The supernatants $(50 \mu \mathrm{L})$ were transferred to clear, flat-bottomed plastic 96-well plates. The concentration of hemoglobin was detected by measuring the OD at $405 \mathrm{~nm}$. The OD of cells incubated with $0.1 \%$ SDS defined $100 \%$ hemolysis, while the OD of cells incubated with PBS buffer defined 0\% hemolysis. The concentrations tested were 200, 400, and $800 \mu \mathrm{g} / \mathrm{mL}$ (only average values for the highest concentration are stated in Table 2).

\subsection{Determination of Antiproliferative Activity on HepG2 Cell Line}

Side effects affecting cell viability were estimated on the HepG2 cell line ATCC HB-8065. In brief, HepG2 cells were seeded in flat-bottomed 96-well plates at a concentration of 5000 cells per well. At $80-90 \%$ confluency, the cells were incubated for $24 \mathrm{~h}$ in a humidified incubator $\left(5 \% \mathrm{CO}_{2}, 37^{\circ} \mathrm{C}\right)$. The medium was removed, and the cells were incubated for $48 \mathrm{~h}$ in a humidified incubator $\left(5 \% \mathrm{CO}_{2}\right.$, $37^{\circ} \mathrm{C}$ ) with compounds in two-fold serial dilutions. An MTT assay was then performed as previously 
described [72]. In brief, after incubation with the test compounds, the culture medium was removed and fresh medium with $0.2 \mathrm{mg} / \mathrm{mL} \mathrm{MTT}$ was added in each well of the plate. After incubation $\left(3 \mathrm{~h}, 37^{\circ} \mathrm{C}\right.$, $5 \% \mathrm{CO}_{2}$ ), the medium with MTT was removed, and $200 \mu \mathrm{L}$ dimethyl sulfoxide were added at once to each sample. Absorbance of MTT was measured using spectrophotometer TECAN Infinite M1000 at $540 \mathrm{~nm}$. The relative viability was calculated by using the formula: $\mathrm{OD}_{\text {treated cells }} \times 100 / \mathrm{OD}_{\text {control cells }}$. The $\mathrm{IC}_{50}$ values are calculated by using the program Graph Pad Prism ${ }^{\circledR}$ 5.0. For all compounds, the test range was $10-1280 \mu \mathrm{g} / \mathrm{mL}$.

\section{Conclusions}

In the present work, we explored how the hydrophobicity and activity profiles (i.e., antibacterial activity versus effect on viability of mammalian cells) of a series of peptide/peptoid hybrid peptidomimetics depend on the structural features termed "relative side-chain length" and "nature of the more flexible residue" (i.e., whether the peptoid units are cationic or hydrophobic).

A general trend within each subgroup was that increased cationic side-chain length confers gradually reduced hydrophobicity, since the amino functionalities become increasingly more accessible to the surroundings due to a lowered shielding by the aromatic groups of the hydrophobic residues. This effect was most distinct for analogues displaying the short cationic Dab or NDab residues, as this feature conferred the highest hydrophobicity within each subgroup. However, extension of the cationic side-chain length beyond that of lysine resulted in a slightly increased hydrophobicity in accordance with an expected hydrophobicity enhancement resulting from the incorporation of additional methylene groups in the cationic side chains, thereby increasing the carbon content relative to the nitrogen/oxygen content.

The peptidomimetics were tested against a panel of seven bacterial strains. None of the peptidomimetics displayed significant activity against K. pneumoniae, and only four displayed activity against $A$. baumannii, while only a few analogues exhibited moderate to low activity against $S$. aureus and E. faecalis, respectively. By contrast, all analogues were active against $E$. coli, with the two least hydrophobic peptidomimetics being the least active, indicating the existence of a hydrophobicity threshold for optimal activity against E. coli. Otherwise, no clear design rules were identified except for the observation that in two of four subgroups the most hydrophobic member was slightly more potent. Most analogues were active against $P$. aeruginosa, and generally a shortening of the cationic side chains by one methylene group gave rise to a two-fold increased potency. This infers that peptidomimetics displaying a hydrophobic surface, comprised of the aromatic groups (partially) shielding the shorter cationic side chains, display more efficient membrane-disruptive interaction with P. aeruginosa.

Testing for hemolytic properties as well as effect on HepG2 cell viability revealed that peptidomimetics displaying the above-mentioned hydrophobic surface proved to be the most hemolytic and affect HepG2 cell viability to the highest degree. Expectedly, high hydrophobicity was clearly correlated to increased effect on HepG2 cell viability, thereby corroborating that for a series of closely related compounds a threshold for acceptable maximal hydrophobicity may typically be identified. Consequently, it is important to: (i) ensure that the surface does not become too hydrophobic (i.e., considerably shorter cationic side chains as compared to the length of the hydrophobic side chains), and (ii) keep the overall hydrophobicity below the threshold that confers extensive toxicity toward mammalian cells regardless of the effects caused by relative side-chain length.

Supplementary Materials: The following are available online, correlations between cationic side-chain length, hydrophobicity, and MIC or IC 50 , HRMS spectra, HPLC chromatograms for all peptidomimetics and building blocks, and HepG2 cell viability curves for peptidomimetics.

Author Contributions: Conceptualisation, N.F., P.R.H., F.B. and H.F; investigation, N.F.; writing-original draft, N.F.; writing-review and editing, N.F., P.R.H., F.B. and H.F.; visualisation, N.F., P.R.H., F.B. and H.F; supervision, H.F.

Funding: Nicki Frederiksen was supported by a PhD grant from the Center for Peptide-Based Antibiotics (CEPAN) financed by the Novo Nordisk Foundation. NMR equipment used in this work was purchased via grant \#10-085264 from the Danish Research Council for Independent Research-Nature and Universe. 
Acknowledgments: We would like to thank Birgitte Simonsen and Uraiwan N. Adamsen for practical help with compound purification and characterisation.

Conflicts of Interest: The authors declare no conflict of interest.

\section{References}

1. Morgan, D.J.; Okeke, I.N.; Laxminarayan, R.; Perencevich, E.N.; Weisenberg, S. Non-prescription antimicrobial use worldwide: A systematic review. Lancet Infect. Dis. 2011, 11, 692-701. [CrossRef]

2. O'Neill, J. Tackling Drug-Resistant Infections Globally: Final Report and Recommendations; The Review on Antimicrobial Resistance: London, UK, 2016.

3. WHO Advisory Group on Integrated Surveillance of Antimicrobial Resistance. Critically Important Antimicrobials for Human Medicine; World Health Organization: Geneva, Switzerland, 2016.

4. The 2019 Expert Committee on the Selection and Use of Essential Medicines. World Health Organization Model List of Essential Medicines; World Health Organization: Geneva, Switzerland, 2019.

5. Arzanlou, M.; Chai, W.C.; Venter, H. Intrinsic, adaptive and acquired antimicrobial resistance in Gram-negative bacteria. Essays Biochem. 2017, 61, 49-59. [CrossRef] [PubMed]

6. Boman, H.G. Peptide antibiotics and their role in innate immunity. Annu. Rev. Immunol. 1995, 13, 61-92. [CrossRef] [PubMed]

7. Jenssen, H.; Hamill, P.; Hancock, R.E.W. Peptide antimicrobial agents. Clin. Microbiol. Rev. 2006, 19, $491-511$. [CrossRef]

8. Zasloff, M. Antimicrobial peptides of multicellular organisms. Nature 2002, 415, 389-395. [CrossRef]

9. Hamamoto, K.; Kida, Y.; Zhang, Y.; Shimizu, T.; Kuwano, K. Antimicrobial activity and stability to proteolysis of small linear cationic peptides with D-amino acid substitutions. Microbiol. Immunol. 2002, 46, 741-749. [CrossRef]

10. Hong, S.Y.; Oh, J.E.; Lee, K.H. Effect of D-amino acid substitution on the stability, the secondary structure, and the activity of membrane-active peptide. Biochem. Pharmacol. 1999, 58, 1775-1780. [CrossRef]

11. Simon, R.J.; Kania, R.S.; Zuckermann, R.N.; Huebner, V.D.; Jewell, D.A.; Banville, S.; Ng, S.; Wang, L.; Rosenberg, S.; Marlowe, C.K.; et al. Peptoids: A modular approach to drug discovery. Proc. Natl. Acad. Sci. USA 1992, 89, 9367-9371. [CrossRef]

12. Kim, J.K.; Lee, S.A.; Shin, S.; Lee, J.Y.; Jeong, K.W.; Nan, Y.H.; Park, Y.S.; Shin, S.Y.; Kim, Y. Structural flexibility and the positive charges are the key factors in bacterial cell selectivity and membrane penetration of peptoid-substituted analog of Piscidin 1. Biochim. Biophys. Acta 2010, 1798, 1913-1925. [CrossRef]

13. Shuey, S.W.; Delaney, W.J.; Shah, M.C.; Scialdone, M.A. Antimicrobial $\beta$-peptoids by a block synthesis approach. Bioorg. Med. Chem. Lett. 2006, 16, 1245-1248. [CrossRef]

14. Porter, E.A.; Weisblum, B.; Gellman, S.H. Mimicry of host-defense peptides by unnatural oligomers: Antimicrobial $\beta$-peptides. J. Am. Chem. Soc. 2002, 124, 7324-7330. [CrossRef] [PubMed]

15. Schmitt, M.A.; Weisblum, B.; Gellman, S.H. Interplay among folding, sequence, and lipophilicity in the antibacterial and hemolytic activities of $\alpha / \beta$-peptides. J. Am. Chem. Soc. 2007, 129, 417-428. [CrossRef] [PubMed]

16. Olsen, C.A.; Bonke, G.; Vedel, L.; Adsersen, A.; Witt, M.; Franzyk, H.; Jaroszewski, J.W. $\alpha$-peptide/ $\beta$-peptoid chimeras. Org. Lett. 2007, 9, 1549-1552. [CrossRef] [PubMed]

17. Padhee, S.; Hu, Y.; Niu, Y.; Bai, G.; Wu, H.; Costanza, F.; West, L.; Harrington, L.; Shaw, L.N.; Cao, C.; et al. Non-hemolytic $\alpha$-AApeptides as antimicrobial peptidomimetics. Chem. Commun. (Camb.) 2011, 47, 9729-9731. [CrossRef]

18. Niu, Y.; Padhee, S.; Wu, H.; Bai, G.; Harrington, L.; Burda, W.N.; Shaw, L.N.; Cao, C.; Cai, J. Identification of $\gamma$-AApeptides with potent and broad-spectrum antimicrobial activity. Chem. Commun. (Camb.) 2011, 47, 12197-12199. [CrossRef]

19. Radzishevsky, I.S.; Rotem, S.; Bourdetsky, D.; Navon-Venezia, S.; Carmeli, Y.; Mor, A. Improved antimicrobial peptides based on acyl-lysine oligomers. Nat. Biotechnol. 2007, 25, 657-659. [CrossRef]

20. Tossi, A.; Sandri, L.; Giangaspero, A. Amphipathic, $\alpha$-helical antimicrobial peptides. Biopolymers 2000, 55, 4-30. [CrossRef]

21. Giangaspero, A.; Sandri, L.; Tossi, A. Amphipathic $\alpha$-helical antimicrobial peptides. Eur. J. Biochem. 2001, 268, 5589-5600. [CrossRef] 
22. Zelezetsky, I.; Pacor, S.; Pag, U.; Papo, N.; Shai, Y.; Sahl, H.G.; Tossi, A. Controlled alteration of the shape and conformational stability of $\alpha$-helical cell-lytic peptides: Effect on mode of action and cell specificity. Biochem. J. 2005, 390, 177-188. [CrossRef]

23. Chen, Y.; Mant, C.T.; Farmer, S.W.; Hancock, R.E.W.; Vasil, M.L.; Hodges, R.S. Rational design of $\alpha$-helical antimicrobial peptides with enhanced activities and specificity/therapeutic index. J. Biol. Chem. 2005, 280, 12316-12329. [CrossRef]

24. Khandelia, H.; Kaznessis, Y.N. Molecular dynamics investigation of the influence of anionic and zwitterionic interfaces on antimicrobial peptides' structure: Implications for peptide toxicity and activity. Peptides 2006, 27, 1192-1200. [CrossRef] [PubMed]

25. Zhang, Y.; Lu, H.; Lin, Y.; Cheng, J. Water-soluble polypeptides with elongated, charged side chains adopt ultra-stable helical conformations. Macromolecules 2011, 44, 6641-6644. [CrossRef] [PubMed]

26. Mangoni, M.L.; Carotenuto, A.; Auriemma, L.; Saviello, M.R.; Campiglia, P.; Gomez-Monterrey, I.; Malfi, S.; Marcellini, L.; Barra, D.; Novellino, E.; et al. Structure-activity relationship, conformational and biological studies of temporin L analogues. J. Med. Chem. 2011, 54, 1298-1307. [CrossRef] [PubMed]

27. Chapuis, H.; Slaninova, J.; Bednarova, L.; Monincova, L.; Budesinsky, M.; Cerovsky, V. Effect of hydrocarbon stapling on the properties of $\alpha$-helical antimicrobial peptides isolated from the venom of hymenoptera. Amino Acids 2012, 43, 2047-2058. [CrossRef] [PubMed]

28. Bobone, S.; Bocchinfuso, G.; Park, Y.; Palleschi, A.; Hahm, K.S.; Stella, L. The importance of being kinked: Role of Pro residues in the selectivity of the helical antimicrobial peptide P5. J. Pept. Sci. 2013, 19, 758-769. [CrossRef] [PubMed]

29. Cherry, M.A.; Higgins, S.K.; Melroy, H.; Lee, H.S.; Pokorny, A. Peptides with the same composition, hydrophobicity, and hydrophobic moment bind to phospholipid bilayers with different affinities. J. Phys. Chem. B 2014, 118, 12462-12470. [CrossRef]

30. Jahnsen, R.D.; Sandberg-Schaal, A.; Vissing, K.J.; Nielsen, H.M.; Frimodt-Møller, N.; Franzyk, H. Tailoring cytotoxicity of antimicrobial peptidomimetics with high activity against multidrug-resistant Escherichia coli. J. Med. Chem. 2014, 57, 2864-2873. [CrossRef]

31. Jahnsen, R.D.; Frimodt-Møller, N.; Franzyk, H. Antimicrobial activity of peptidomimetics against multidrug-resistant Escherichia coli: A comparative study of different backbones. J. Med. Chem. 2012, 55, 7253-7261. [CrossRef]

32. Lee, J.; Kang, D.; Choi, J.; Huang, W.; Wadman, M.; Barron, A.E.; Seo, J. Effect of side chain hydrophobicity and cationic charge on antimicrobial activity and cytotoxicity of helical peptoids. Bioorg. Med. Chem. Lett. 2018, 28, 170-173. [CrossRef]

33. Yin, L.M.; Edwards, M.A.; Li, J.; Yip, C.M.; Deber, C.M. Roles of hydrophobicity and charge distribution of cationic antimicrobial peptides in peptide-membrane interactions. J. Biol. Chem. 2012, 287, 7738-7745. [CrossRef]

34. Rosenfeld, Y.; Lev, N.; Shai, Y. Effect of the hydrophobicity to net positive charge ratio on antibacterial and anti-endotoxin activities of structurally similar antimicrobial peptides. Biochemistry 2010, 49, 853-861. [CrossRef] [PubMed]

35. Blondelle, S.E.; Houghten, R.A. Hemolytic and antimicrobial activities of the twenty-four individual omission analogues of melittin. Biochemistry 1991, 30, 4671-4678. [CrossRef] [PubMed]

36. Kondejewski, L.H.; Jelokhani-Niaraki, M.; Farmer, S.W.; Lix, B.; Kay, C.M.; Sykes, B.D.; Hancock, R.E.W.; Hodges, R.S. Dissociation of antimicrobial and hemolytic activities in cyclic peptide diastereomers by systematic alterations in amphipathicity. J. Biol. Chem. 1999, 274, 13181-13192. [CrossRef] [PubMed]

37. Tachi, T.; Epand, R.F.; Epand, R.M.; Matsuzaki, K. Position-dependent hydrophobicity of the antimicrobial magainin peptide affects the mode of peptide-lipid interactions and selective toxicity. Biochemistry 2002, 41, 10723-10731. [CrossRef] [PubMed]

38. Molchanova, N.; Hansen, P.R.; Damborg, P.; Nielsen, H.M.; Franzyk, H. Lysine-Based $\alpha$-Peptide/ $\beta$-Peptoid Peptidomimetics: Influence of Hydrophobicity, Fluorination, and Distribution of Cationic Charge on Antimicrobial Activity and Cytotoxicity. ChemMedChem 2017, 12, 312-318. [CrossRef] [PubMed]

39. Jahnsen, R.O.; Sandberg-Schaal, A.; Frimodt-Møller, N.; Nielsen, H.M.; Franzyk, H. End group modification: Efficient tool for improving activity of antimicrobial peptide analogues towards Gram-positive bacteria. Eur. J. Pharm. Biopharm. 2015, 95, 40-46. [CrossRef] 
40. Tan, J.; Huang, J.; Huang, Y.; Chen, Y. Effects of single amino acid substitution on the biophysical properties and biological activities of an amphipathic $\alpha$-helical antibacterial peptide against Gram-negative bacteria. Molecules 2014, 19, 10803-10817. [CrossRef]

41. Glukhov, E.; Burrows, L.L.; Deber, C.M. Membrane interactions of designed cationic antimicrobial peptides: The two thresholds. Biopolymers 2008, 89, 360-371. [CrossRef]

42. Molchanova, N.; Hansen, P.R.; Damborg, P.; Franzyk, H. Fluorinated antimicrobial lysine-based peptidomimetics with activity against methicillin-resistant Staphylococcus pseudintermedius. J. Pept. Sci. 2018, 24, e3098. [CrossRef]

43. Chongsiriwatana, N.P.; Miller, T.M.; Wetzler, M.; Vakulenko, S.; Karlsson, A.J.; Palecek, S.P.; Mobashery, S.; Barron, A.E. Short alkylated peptoid mimics of antimicrobial lipopeptides. Antimicrob. Agents Chemother. 2011, 55, 417-420. [CrossRef]

44. Chu-Kung, A.F.; Bozzelli, K.N.; Lockwood, N.A.; Haseman, J.R.; Mayo, K.H.; Tirrell, M.V. Promotion of peptide antimicrobial activity by fatty acid conjugation. Bioconjug. Chem. 2004, 15, 530-535. [CrossRef] [PubMed]

45. Radzishevsky, I.S.; Rotem, S.; Zaknoon, F.; Gaidukov, L.; Dagan, A.; Mor, A. Effects of acyl versus aminoacyl conjugation on the properties of antimicrobial peptides. Antimicrob. Agents Chemother. 2005, 49, 2412-2420. [CrossRef] [PubMed]

46. Zweytick, D.; Pabst, G.; Abuja, P.M.; Jilek, A.; Blondelle, S.E.; Andra, J.; Jerala, R.; Monreal, D.; Martinez de Tejada, G.; Lohner, K. Influence of N-acylation of a peptide derived from human lactoferricin on membrane selectivity. Biochim. Biophys. Acta 2006, 1758, 1426-1435. [CrossRef]

47. Bolt, H.L.; Eggimann, G.A.; Jahoda, C.A.B.; Zuckermann, R.N.; Sharples, G.J.; Cobb, S.L. Exploring the links between peptoid antibacterial activity and toxicity. MedChemComm 2017, 8, 886-896. [CrossRef] [PubMed]

48. Pasupuleti, M.; Schmidtchen, A.; Chalupka, A.; Ringstad, L.; Malmsten, M. End-tagging of ultra-short antimicrobial peptides by W/F stretches to facilitate bacterial killing. PLoS ONE 2009, 4, e5285. [CrossRef]

49. Gatto, E.; Mazzuca, C.; Stella, L.; Venanzi, M.; Toniolo, C.; Pispisa, B. Effect of peptide lipidation on membrane perturbing activity: A comparative study on two trichogin analogues. J. Phys. Chem. B 2006, 110, 22813-22818. [CrossRef]

50. Schmidtchen, A.; Pasupuleti, M.; Morgelin, M.; Davoudi, M.; Alenfall, J.; Chalupka, A.; Malmsten, M. Boosting antimicrobial peptides by hydrophobic oligopeptide end tags. J. Biol. Chem. 2009, 284, 17584-17594. [CrossRef]

51. Schmidtchen, A.; Ringstad, L.; Kasetty, G.; Mizuno, H.; Rutland, M.W.; Malmsten, M. Membrane selectivity by W-tagging of antimicrobial peptides. Biochim. Biophys. Acta 2011, 1808, 1081-1091. [CrossRef]

52. Schmidtchen, A.; Pasupuleti, M.; Malmsten, M. Effect of hydrophobic modifications in antimicrobial peptides. Adv. Colloid Interface Sci. 2014, 205, 265-274. [CrossRef]

53. Olsen, C.A.; Ziegler, H.L.; Nielsen, H.M.; Frimodt-Møller, N.; Jaroszewski, J.W.; Franzyk, H. Antimicrobial, hemolytic, and cytotoxic activities of $\beta$-peptoid-peptide hybrid oligomers: Improved properties compared to natural AMPs. ChemBioChem 2010, 11, 1356-1360. [CrossRef]

54. Rice, L.B. Federal funding for the study of antimicrobial resistance in nosocomial pathogens: No ESKAPE. J. Infect. Dis. 2008, 197, 1079-1081. [CrossRef] [PubMed]

55. Molchanova, N.; Wang, H.; Hansen, P.R.; Hoiby, N.; Nielsen, H.M.; Franzyk, H. Antimicrobial ity of $\alpha$-Peptide/ $\beta$-Peptoid Lysine-Based Peptidomimetics Against Colistin-Resistant Pseudomonas aeruginosa Isolated From Cystic Fibrosis Patients. Front. Microbiol. 2019, 10, 275. [CrossRef] [PubMed]

56. Kruijtzer, J.A.W.; Hofmeyer, L.J.F.; Heerma, W.; Versluis, C.; Liskamp, R.M.J. Solid-Phase Syntheses of Peptoids using Fmoc-ProtectedN-Substituted Glycines: The Synthesis of (Retro)Peptoids of Leu-Enkephalin and Substance P. Chem. Eur. J. 1998, 4, 1570-1580. [CrossRef]

57. Chen, C.X.; Hu, J.; Yang, C.; Zhang, Y.; Wang, F.; Mu, Q.M.; Pan, F.; Xu, H.; Lu, J.R. Amino acid side chains affect the bioactivity of designed short peptide amphiphiles. J. Mater. Chem. B 2016, 4, 2359-2368. [CrossRef]

58. Hein-Kristensen, L.; Knapp, K.M.; Franzyk, H.; Gram, L. Bacterial membrane activity of $\alpha$-peptide/ $\beta$-peptoid chimeras: Influence of amino acid composition and chain length on the activity against different bacterial strains. BMC Microbiol. 2011, 11, 1-12. [CrossRef]

59. Chongsiriwatana, N.P.; Patch, J.A.; Czyzewski, A.M.; Dohm, M.T.; Ivankin, A.; Gidalevitz, D.; Zuckermann, R.N.; Barron, A.E. Peptoids that mimic the structure, function, and mechanism of helical antimicrobial peptides. Proc. Natl. Acad. Sci. USA 2008, 105, 2794-2799. [CrossRef] 
60. Shi, Y.; Teng, P.; Sang, P.; She, F.; Wei, L.; Cai, J. $\gamma$-AApeptides: Design, structure, and applications. Acc. Chem. Res. 2016, 49, 428-441. [CrossRef]

61. Bolarinwa, O.; Nimmagadda, A.; Su, M.; Cai, J. Structure and function of AApeptides. Biochemistry 2017, 56, 445-457. [CrossRef]

62. Epand, R.M.; Epand, R.F. Lipid domains in bacterial membranes and the action of antimicrobial agents. Biochim. Biophys. Acta 2009, 1788, 289-294. [CrossRef]

63. Epand, R.M.; Epand, R.F. Bacterial membrane lipids in the action of antimicrobial agents. J. Pept. Sci. 2011, 17, 298-305. [CrossRef]

64. Nikaido, H. Molecular basis of bacterial outer membrane permeability revisited. Microbiol. Mol. Biol. Rev. 2003, 67, 593-656. [CrossRef] [PubMed]

65. Mojsoska, B.; Zuckermann, R.N.; Jenssen, H. Structure-activity relationship study of novel peptoids that mimic the structure of antimicrobial peptides. Antimicrob. Agents Chemother. 2015, 59, 4112-4120. [CrossRef] [PubMed]

66. Dathe, M.; Wieprecht, T.; Nikolenko, H.; Handel, L.; Maloy, W.L.; MacDonald, D.L.; Beyermann, M.; Bienert, M. Hydrophobicity, hydrophobic moment and angle subtended by charged residues modulate antibacterial and haemolytic activity of amphipathic helical peptides. FEBS Lett. 1997, 403, 208-212. [CrossRef]

67. Kondejewski, L.H.; Lee, D.L.; Jelokhani-Niaraki, M.; Farmer, S.W.; Hancock, R.E.W.; Hodges, R.S. Optimization of microbial specificity in cyclic peptides by modulation of hydrophobicity within a defined structural framework. J. Biol. Chem. 2002, 277, 67-74. [CrossRef] [PubMed]

68. Stark, M.; Liu, L.P.; Deber, C.M. Cationic hydrophobic peptides with antimicrobial activity. Antimicrob. Agents Chemother. 2002, 46, 3585-3590. [CrossRef] [PubMed]

69. Chen, Y.; Guarnieri, M.T.; Vasil, A.I.; Vasil, M.L.; Mant, C.T.; Hodges, R.S. Role of peptide hydrophobicity in the mechanism of action of $\alpha$-helical antimicrobial peptides. Antimicrob. Agents Chemother. 2007, 51, 1398-1406. [CrossRef]

70. Uggerhøj, L.E.; Poulsen, T.J.; Munk, J.K.; Fredborg, M.; Søndergaard, T.E.; Frimodt-Møller, N.; Hansen, P.R.; Wimmer, R. Rational design of $\alpha$-helical antimicrobial peptides: Do's and don'ts. ChemBioChem 2015, 16, 242-253. [CrossRef]

71. Modified MIC Method for Cationic Antimicrobial Peptides. Available online: http://cmdr.ubc.ca/bobh/ method/modified-mic-method-for-cationic-antimicrobial-peptides/ (accessed on 3 October 2019).

72. Mosmann, T. Rapid colorimetric assay for cellular growth and survival: Application to proliferation and cytotoxicity assays. J. Immunol. Methods 1983, 65, 55-63. [CrossRef] 